\title{
THE COMPUTATION OF OCEANIC AND METEOROLOGICAL FIELDS OF MOTION WITH FRICTION PROPORTIONAL \\ TO THE VELOCITY
}

\author{
by \\ KLAUS WYRTKI
}

\begin{abstract}
SUMMARY
The friction in the hydrodynamical differential equations is taken proportional to the velocity. With it simple relations result, permitting the calculation of the mass transport, without the need to solve differential equations, if the wind and pressure distributions are known. The solution can cross the equator freely. Simultaneously the equations give the vertical components of motion at the lower boundary of the layer under consideration. Numerical values of the friction coefficient are given, and oceanographical and meteorological models are discussed, as for instance the monsoon winds over Southeast Asia, the monsoon currents in the Java and China Seas and the equatorial currents of the Pacific Ocean.
\end{abstract}

\section{ZUSAMMENFASSUNG}

Die Reibung wird in den hydrodynamischen Differentialgleichungen proportional der Geschwindigkeit angesetzt. Damit ergeben sich einfache Beziehungen, die es gestatten, bei Kenntnis der Wind- und Druckverteilung die Massentransporte zu berechnen, ohne Differentialgleichungen losen zu mussen. Die Losungen konnen den Aquator beliebig uberschreiten. Gleichzeitig liefern die Gleichungen die vertikalen Bewegungskomponenten an der Unterkante der betrachteten Schicht. Angaben uber die Grosse des Reibungskoeffizienten werden gemacht und Beispiele aus der Meteorologie und Ozeanographie werden diskutiert, so die Monsunwinde uber Sudostasien, die Monsunstromungen in der Java- und China- See und die aquatorialen Stromungen im Pazifischen Ozean.

\section{ICHTISAR}

Gesekan dalam perbandingan-perbandingan diferensial hydrodinamis, diperoleh sebanding dengan ketjepatan. Dengan hasil perhubungannja jang sederhana, memungkinkan perhitungan dari pemindahan setjara masal, tidak usah membutuhkan pemetjahan dari perbandingan-perbandingan diferensial itu, apabila peredaran angin dan tekenan telah diketahui. Pendapatan itu dapat melintasi chatulistiwa dengan bebas. Bersamaan dengan itu perbandingan-perbandingan tersebut memberikan bagian-bagian gerakan setjara menegak dibatas bawah daripada lapisan jang dimaksud. Beberapa nilai dari koefisien gesekan telah diberikan dan model-model oceanografis dan meteorologis telah dikupas, misalnja mengenai angin musim di-Asia Tenggara, arus musim di-Laut Djawa dan Laut Tiongkok dan arus chatulistiwa dari Lautan Teduh. 


\section{INTRODUCTION}

In physical oceanography the determination of the field of motion is most importend, but also most complicated. Its determination requires the observation of a three-dimensional vector field, variable also in time, which is naturally most difficult. Therefore the possibilities of its direct determination are limited, and one often changes to indirect methods which permit obtaining results on the distribution of velocity. On the one hand, one can turn back to scalar fields, the distribution of density and pressure, or one can use the boundary conditions, the distribution of the stress of wind, of which a detailed observation is possible. From these, the field of motion can be derived by means of the hydrodynamical differential equations.

In recent years there has been a step forward in considering the topography of the sea level to be primarily an effect of the wind, so that it becames possible to derive the whole circulation from the distribution of wind stress only. But this assumption neglects the fact that water masses of different densities are formed in the different climatic regions, which must produce currents at their boundaries. The formation of specific water masses leads to a continuous increase of the potential energy in certain regions of the oceans. The exclusive use of the distribution of wind stress for the determination of the motion and of the topography of the sea level leads to partial differential equations, which on principle can be solved, if the necessary boundary conditions are given.

The boundary conditions are trivial, if the circulation takes place in a completely enclosed basin, because they are based on the physically logical assumptions that at the boundary the normal component of the velocity and its derivation must vanish. For such enclosed basins the differential equation gives solutions, showing the gross features of the circulation in relatively good agreement with the observations, as modern investigations have shown.

If, on the other hand, a solution is required for a region not enclosed by natural boundaries, the boundary conditions must be observed. But to avoid this was the primary purpose for the application of these theories, because the assumptions which must be made in the case of a region which is not enclosed, are mostly so fareaching that they anticipate the solution. The real deficiency of these theories is that their application is limited to completely enclosed basins and can be used only definitly for the treatment of oceanographical observations in limited regions.

Because the consideration of the stress of wind is equivalent to a continuous addition of energy to the ocean, it is necessary to make use 
of the dissipation terms in the hydrodynamic equations. Presently this is done in two different ways, using the diffusion of the impulse, which leads to the coefficients of horizontal $\mathrm{A}^{\mathrm{h}}$ and vertical $\mathrm{A}^{\mathrm{v}}$ eddy viscosity, or taking the friction $\mathrm{R}$ proportional to the velocities, $\mathrm{R}-\mathrm{r} \mathrm{v}$, as common in hydraulics. The use of $\mathrm{A}^{\mathrm{h}}$ and $\mathrm{A}^{\mathrm{v}}$ leads to differential equations of relative high order, moreover the coefficients themselves are determinated only insufficient and depend on the size of the movements under consideration. A view on the tables given by SVERDRUP (1946) for $\mathrm{A}^{\mathrm{h}}$ and $\mathrm{A}^{\mathrm{v}}$ shows how unsatisfactory calculations must become, using these coefficients. On the other hand the use of the linear friction coefficient simplifies the treatment of the hydrodynamical equations, especially in the case of numerical calculations, as shown by HANSEN (1951). But values of the friction coefficient $r$ are not yet known accurately enough and must be determinated. This paper shall be a contribution in this direction.

Theory. The investigations are basing on the hydrodynamical differential equations in the form

$$
\begin{gathered}
\varrho f v+A^{h} \Delta u+A^{v} u_{z z}-p_{x}=0 \\
-\varrho f u+A^{h} \Delta v+A^{v} v_{z z}-p_{y}=0 \\
p_{z}=\varrho g \\
u_{x}+v_{y}+w_{z}=0
\end{gathered}
$$

Therefor it is assumed that the movements are stationary, that the inertial terms can be omitted, and that the vertical movements are of importance only for the equation of continuity. ROSSBY (1936) has shown for the Gulf Stream that it is not always possible to drop the nonlinear terms, especially not in regions with high velocities and velocity gradients. There are $\mathrm{u}, \mathrm{v}, \mathrm{w}$ the components of the velocity in $\mathrm{x}, \mathrm{y}, \mathrm{z}$ - direction, respectively, $Q$ the density, $g$ the acceleration of the earth, $f-2 \omega \sin \varphi$ the coriolis parameter, $\mathrm{A}^{\mathrm{h}}$ the horizontal and $\mathrm{A}^{\mathrm{v}}$ the vertical eddy viscosity and $\Delta$ the Laplace operator. The $\mathrm{x}$-axis points eastward, the $\mathrm{y}$-axis northward and the $\mathrm{z}$-axis positive down.

Integrating this system from the surface to the depth $\mathrm{D}$, about which restrictions need not yet be made, and assuming that

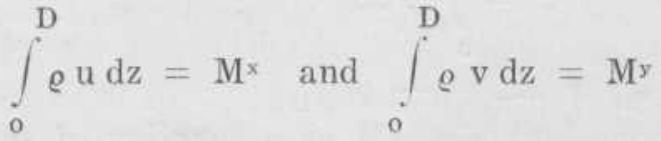

are the components of the mass transport $\mathrm{M}$, and that

$$
\left(\mathrm{A}^{\mathrm{v}} \mathrm{u}_{\mathrm{z}}\right)_{0}=-\tau^{\mathrm{x}} \text { and }\left(\mathrm{A}^{\mathrm{v}} \mathrm{v}_{\mathrm{z}}\right)_{0}=-\tau^{\mathrm{y}}
$$


are the components of the wind stress $r$, which can be assumed to be known, the system (1) becomes

$$
\begin{gathered}
\mathrm{fM}^{\mathrm{y}}+\frac{\mathrm{A}^{\mathrm{h}}}{\varrho} \Delta \mathrm{M}^{\mathrm{x}}+\left(\mathrm{A}^{\mathrm{v}} \mathrm{u}_{\mathrm{z}}\right)_{\mathrm{D}}+\tau^{\mathrm{x}}-\mathrm{P}_{\mathrm{x}}=0 \\
-\mathrm{f} \mathrm{M}^{\mathrm{x}}+\frac{\mathrm{A}^{\mathrm{h}}}{\varrho} \Delta \mathrm{M}^{\mathrm{y}}+\left(\mathrm{A}^{\mathrm{v}} \mathrm{v}_{\mathrm{z}}\right)_{\mathrm{D}}+\tau^{\mathrm{y}}-\mathrm{P}_{\mathrm{y}}=\mathrm{O} \\
\mathrm{P}=\int_{0}^{\mathrm{D}} \mathrm{pdz} / \mathrm{p}=\int_{0}^{\mathrm{z}} \varrho \mathrm{gdz} \\
\mathrm{M}_{\mathrm{x}}^{\mathrm{x}}+\mathrm{M}_{\mathrm{y}}^{\mathrm{y}}=-\varrho \mathrm{W}_{\mathrm{D}}
\end{gathered}
$$

Only in the special case that there are no vertical movements in the depth $\mathrm{D}$, the divergence of mass transport vanishes. Combining the terms representing the friction, and assuming them to be proportional to the mass transport $\mathrm{M}$, it is

$$
\begin{aligned}
& \frac{\mathrm{A}^{\mathrm{h}}}{\varrho} \Delta \mathrm{M}^{\mathrm{x}}+\left(\mathrm{A}^{\mathrm{v}} \mathrm{u}_{\mathrm{z}}\right)_{\mathrm{D}}=-r \mathrm{M}^{\mathrm{x}} \\
& \frac{\mathrm{A}^{\mathrm{h}}}{\varrho} \Delta \mathrm{M}^{\mathrm{y}}+\left(\mathrm{A}^{\mathrm{v}} \mathrm{v}_{\mathrm{z}}\right)_{\mathrm{D}}=-\mathrm{r} \mathrm{M}^{\mathrm{y}}
\end{aligned}
$$

and $\mathrm{r}$ is the friction coefficient. The friction consists of two terms, the internal friction, represented by the horizontal eddy viscosity, and the boundary friction in the depth D. From this it follows that the coefficient of friction will depend on whether or not the velocity gradient in the depth D vanishes. The zero-layer, used by DEFANT (1941) in the Atlantic Ocean has been chosen in a depth where the vertical gradient of the horizontal velocity vanishes, and it has been assumed that in that depth the horizontal velocity itself vanishes. Using such a depth, the coefficient $r$ must become extremely small. It would be quite different if $\mathrm{D}$ is the bottom of a shallow sea, because than the bottom friction might be the predominate factor, and $\mathrm{r}$ would become relatively large. Introducing (5) into (4) the system (1) becomes

$$
\begin{aligned}
& -f M^{y}+r M^{x}=\tau^{x}-P_{x} \\
& \mathrm{f} \mathrm{M}^{\mathrm{x}}+\mathrm{r} \mathrm{M}^{y}=\tau^{y}-\mathrm{P}_{\mathrm{y}} \\
& \mathrm{P}=\int_{0}^{\mathrm{D}} \mathrm{pdz} \\
& \mathrm{M}_{\mathrm{x}}^{\mathrm{x}}+\mathrm{M}_{\mathrm{y}}^{\mathrm{y}} \stackrel{0}{=}-\varrho \mathrm{w}_{\mathrm{D}}
\end{aligned}
$$

This system of equations gives $\mathrm{M}$ as a function of the distribution of wind stress and pressure. $\mathrm{P}$ is to be calculated from the distribution of mass. 
Because the topography of the sea surface is essentially affected by the winds, in the last years the attempt has been made to present the mass transport $\mathrm{M}$ as a function of the wind stress $x$ alone, STOMMEL (1948), MuNK (1950), HidAKA (1950 and 1955), HANSEN (1951). A stream function $\Psi$ is introduced with

This leads necessarily to

$$
\mathrm{M}^{\mathrm{x}}=\psi_{\mathrm{y}} \text { and } \mathrm{M}^{\mathrm{y}}=-\psi_{\mathrm{x}}
$$

$$
\mathrm{M}_{\mathrm{x}}^{\mathrm{x}}+\mathrm{M}_{\mathrm{y}}^{\mathrm{y}}=\mathrm{O} \text { and } \mathrm{w}_{\mathrm{D}}=\mathrm{O}
$$

It follows that, in the case of the introduction of a stream function, D must be a depth in which the vertical movements vanish. This has been pointed out by HANSEN (1951), but in his calculations for the equatorial parts of the Atlantic Ocean he does not use this restriction. Already in a depth of $200 \mathrm{~m}$ he assumes these movements to play an unimportant role which, however, is not confirmed. HIDAKA (1955), on the other hand, has derived from a similar equation the divergence in the upper 100 to $200 \mathrm{~m}$ of the Pacific Ocean, and obtains considerable values, the distribution of which is in fair agreement with the observations. Also NEUMANN (1954) does not consider this necessary when using for D the zero-layer of DEFANT (1941). Probably a considerable vertical transport takes place through this layer, which has been made plausible by WtJST (1950), discussing the general circulation of the Atlantic Ocean.

Cross differentiation of (6) and use of the stream function $\Psi$ gives the differential equation

$$
\mathrm{f}_{\mathrm{y}} \psi_{\mathrm{x}}+\mathrm{r} \Delta \psi=\mathrm{x}_{\mathrm{y}}^{\mathrm{x}}-\tau_{\mathrm{x}}^{\mathrm{y}} \text { for } \mathrm{D}=\text { const. }
$$

Also a variable D can be considered, as done by NEUMANN (1954), but in every case it is necessary that in the depth $\mathrm{D}$ the vertical movements vanish. That is always satisfied if $\mathrm{D}$ is the very bottom. This equation permits the determination of the stream function, as well as of the topography of the sea level. This can be done analytically or numerically as done by HANSEN (1951) for the Atlantic Ocean.

An alternate method can be used if, beside the distribution of the wind stress, the distribution of pressure resulting from hydrographic observations is assumed to be known. In this case the system (6) can be solved directly for $\mathrm{M}^{\mathrm{x}}$ and $\mathrm{M}^{\mathrm{y}}$ and gives, moreover, the vertical velocity $\mathrm{W}_{\mathrm{D}}$ in the depth $\mathrm{D}$. For investigations which do not concern a totaly enclosed basin, but only a part of the ocean, this might be an advantage. Moreover, it is not necessary to solve a differential equation. In most of these cases it will be possible to choose the depth D in such a way that 
the density $Q$ is constant within $\mathrm{D}$. Than the system of equations becomes very simple. The pressure $\mathrm{p}$ is given as a function of $\mathrm{z}, \mathrm{p}=Q \mathrm{~g}(\mathrm{z}+\mathrm{h})$, where $\mathrm{h}$ is the topography of the sea level.

$$
\begin{gathered}
-f M^{y}+r M^{x}=\tau^{x}-\varrho g D h_{x} \\
f M^{x}+r M^{y}=\tau^{y}-\varrho g D h_{y} \\
P=\varrho g D\left(\frac{D}{2}+h\right) \\
M_{x}^{x}+M_{y}^{y}=-\varrho w_{D}
\end{gathered}
$$

The elimination of $\mathrm{M}$ gives

$$
\begin{aligned}
& \left(\mathrm{f}^{2}+\mathrm{r}^{2}\right) \mathrm{M}^{\mathrm{x}}=\mathrm{r} \tau^{\mathrm{x}}+\mathrm{f} \tau^{\mathrm{y}}-\mathrm{r} \varrho \mathrm{gDh}-\mathrm{f} \varrho \mathrm{gDh} \\
& \left(\mathrm{f}^{2}+\mathrm{r}^{2}\right) \mathrm{M}^{\mathrm{y}}=\mathrm{r} \tau^{\mathrm{y}}-\mathrm{f} \tau^{\mathrm{x}}+\mathrm{f} \varrho \mathrm{gDh}-\mathrm{r} \varrho \mathrm{gDh} y
\end{aligned}
$$

and shows the components of the mass transport as a function of the components of the wind stress and of the slopes of the sea level. The solution can cross the equator without becoming infinite. Because a stream function is not used, it is not necessary that $\operatorname{div} \mathrm{M}=0$, and the equations (7) permit calculating the divergence of the layer $\mathrm{D}$.

At oceanic models, where the wind stress differs from zero, the equations (7) always give the mass transport $\mathrm{M}$, or at constant density the volume transport $\mathrm{V}$. At meteorological models it becomes possible to divide by $\mathrm{D}$, which gives a simple system, with only the components of the velocities and the atmospheric pressure.

$$
\begin{aligned}
-\mathrm{f} v+r u & =\frac{1}{\varrho} p_{\mathrm{x}} \\
\mathrm{fu}+\mathrm{rv} & =\frac{1}{\varrho} \mathrm{p}_{\mathrm{y}} \\
\mathrm{u}_{\mathrm{x}}+\mathrm{v}_{\mathrm{y}} & =-\mathrm{w}_{\mathrm{z}}
\end{aligned}
$$

The friction coefficient $r$. Before further investigations it becomes necessary to study the numerical values of the coefficient $r$ and the basic properties of the equations (8). For this purpose they can be written in the form

$$
\begin{aligned}
& r \mathrm{M}^{\mathrm{x}}-\mathrm{f} \mathrm{M}^{\mathrm{y}}=\mathrm{K}^{\mathrm{x}} \\
& \mathrm{f}^{\mathrm{x}}+r \mathrm{M}^{\mathrm{y}}=\mathrm{K}^{\mathrm{y}}
\end{aligned}
$$

where the components of the stress $\mathrm{K}$ are given by

$$
\mathrm{K}^{\mathrm{x}}=\tau^{\mathrm{x}}-\varrho \mathrm{gDh}_{\mathrm{x}} \quad \text { and } \quad \mathrm{K}^{\mathrm{y}}=r^{\mathrm{y}}-\varrho \mathrm{g} \mathrm{Dh} \mathrm{y}
$$

Then equation (10) combines the vector of the mass transport $\mathrm{M}$ with the vector of the stress K. Elimination of $M$ gives

$$
\begin{aligned}
& M^{x}=\frac{1}{f^{2}+r^{2}}\left(r K^{x}+f K^{y}\right) \\
& M^{y}=\frac{1}{f^{2}+r^{2}}\left(r K^{y}-f K^{x}\right)
\end{aligned}
$$




\section{Introducing}

$$
\begin{array}{lll}
\mathrm{K}^{\mathrm{x}}=\mathrm{K} \cos \beta & & \mathrm{M}^{\mathrm{x}}=\mathrm{M} \cos \gamma \\
\mathrm{K}^{\mathrm{y}}=\mathrm{K} \sin \beta & \text { and } & \mathrm{M}^{\mathrm{y}}=\mathrm{M} \sin \gamma
\end{array}
$$

a simple calculation gives

$$
\begin{gathered}
M=\frac{K}{\sqrt{f^{2}+r^{2}}} \\
\cos (\gamma-\beta)=\frac{-r}{\sqrt{f^{2}+r^{2}}}
\end{gathered}
$$

Because $\mathrm{r}$ never becomes zero, $\mathrm{M}$ is defined also at the equator. The expression (12) combines the magnitude of the mass transport $\mathrm{M}$ or of the velocity $\mathrm{c}$ with the stress $\mathrm{K}$. In geostrophic currents $M=\frac{K}{f}$, where $\mathrm{K}$ must become zero at the equator and the mass transport would be indeterminated. The function $\frac{1}{\sqrt{f^{2}+r^{2}}}$ is represented in Fig. 1 for different values of $r$ as a function of latitude. The curve $r=0$ corresponds to geostrophic currents. It is apparent that the influence of the friction is especially remarkable in the vicinity of the equator. At small friction, $r$ $<2.10-^{5}$ sec- $^{1}$ the curves approximate closely the curve for $\mathrm{r}=0$ and deviate only in lower latitudes. At higher friction the function is relatively independent of latitude.

The angle between the vector of the stress and the vector of the mass transport according to (13) is represented in Fig. 2. It depends considerably on latitude, and reaches from $0^{\circ}$ at the equator to about $90^{\circ}$ at the poles. In the geostrophic case the angle is constantly $90^{\circ}$. Crossing the equator it jumps from $90^{\circ}$ to $-90^{\circ}$. At small friction, $\mathrm{r}<1 \mathrm{O}^{5} \mathrm{sec}^{1}$, the angle increases from $0^{\circ}$ at the equator rapidly to high values, in $20^{\circ}$ latitude it has already reached $80^{\circ}$. At higher friction the increase is more gradual, at the poles $90^{\circ}$ will never be reached.

It is very difficult to calculate values of $r$, using equation (12) because observations of the transport must be compared with observations of the stress, and both are difficult to observe. Few determinations already made are reported in table 1.

The determination of the coefficient $r$ is simpler, using equation (13), which gives the angle of deflection as a function of the latitude. The Dutch Climatic Atlases for the China Sea and the waters around Australia, showing the resulting winds for $1^{\circ}$ squares superimposed by the distribution of pressure, are especially suitable for this purpose. This allows an easy reading of the angle between the direction of the wind and of the pressure gradient. From these results the curve I in Fig. 2, showing 


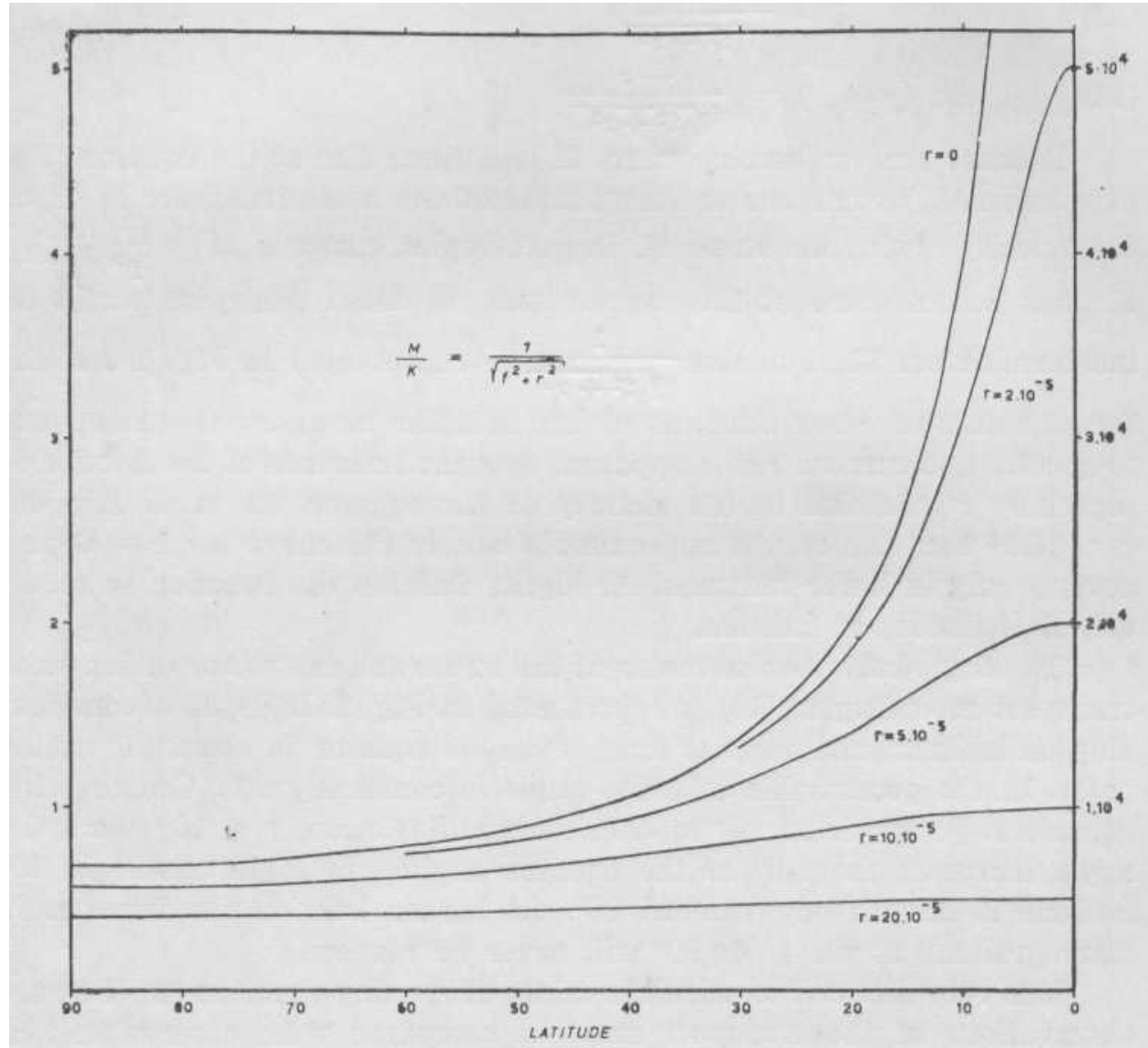

Fig. 1. Factor between mass transport and stress as a function of latitude for different friction coefficients. 


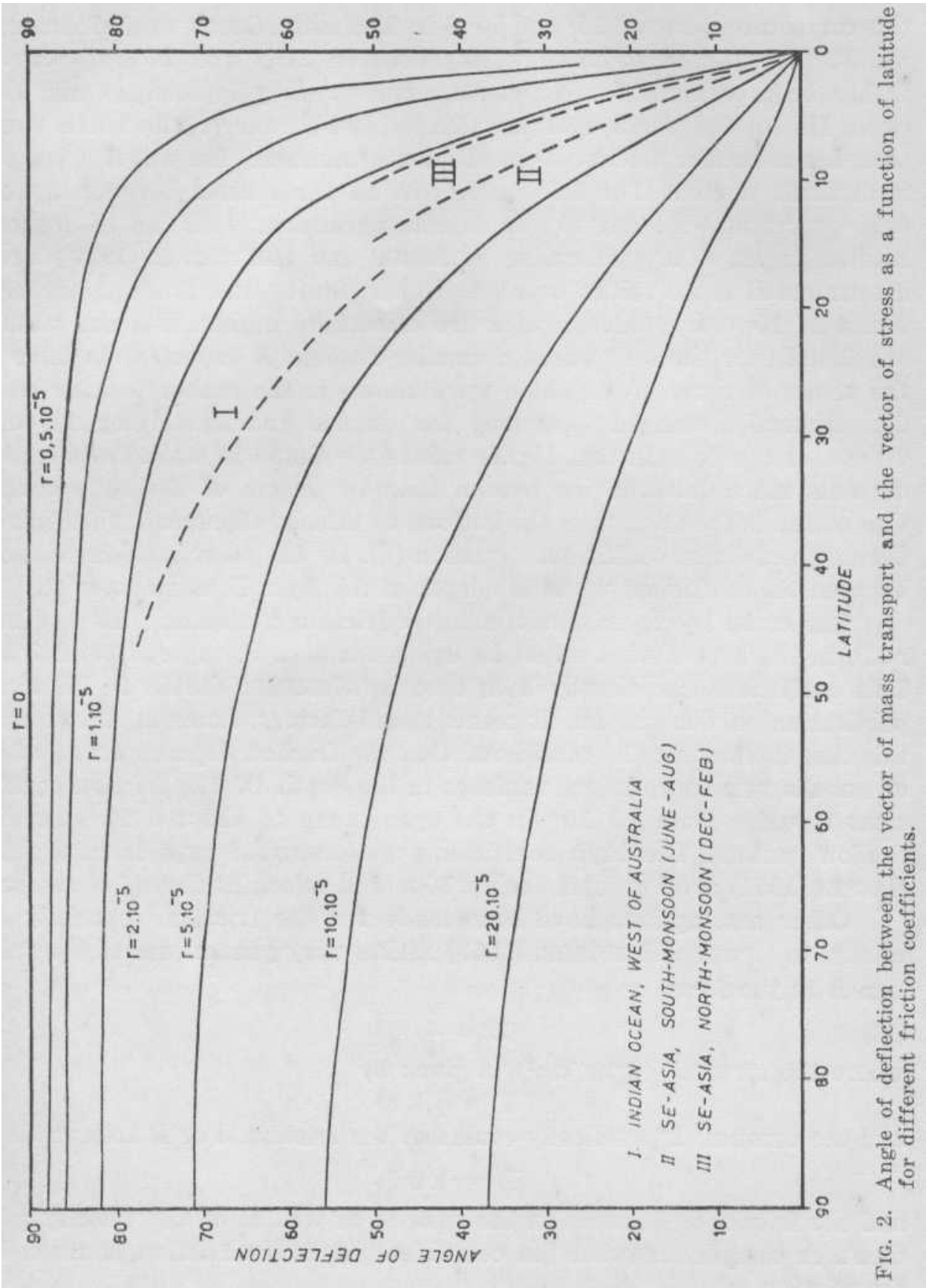


this correlation between $15^{\circ}$ and $50^{\circ} \mathrm{S}$ in the Indian Ocean west of Australia. For the Southeast Asian waters between $20^{\circ} \mathrm{N}$ and $20^{\circ} \mathrm{S}$ the curve II has been obtained for the south monsoon (July-September) and the curve III for the north monsoon (December-February). The north monsoon has a smaller friction then the south monsoon, for which a reason is difficult to give. The friction lies in all three cases between 2 and $410^{-5} \mathrm{sec}^{-1}$, and the curves run in fair agreement with the theoretical results. In an older publication SVERDRUP and HOLTSMARK (1917) have determinated these values over the United States and found $r$ between 7 and $2710^{-5} \mathrm{sec}^{-1}$, values which are essentially higher. But our values are found over the sea, where a smaller friction is expected. In table 1 the values of $r$ are given which were known to the author to have been determinated, arranged separately for oceanic and meteorological conditions. It can be seen that higher values are found in waters where the currents reach towards the bottom than in waters of the open ocean. The reason is the friction at the bottom, as already discussed, when introducing the friction coefficient, equation (5). On the other hand, a relation between the coefficient $r$ and the depth of the layer D seems to exist.

One could try to introduce another friction coefficient, the product $r$. $\mathrm{D}$, in the hope that it might be independent of the special conditions. This coefficient has already been used by STOMMEL (1948) in his first publication on this subject. It seems unsatisfactory, however, because in this case it must also be considered that the friction depends on whether or not the velocity gradient vanishes in the depth $\mathrm{D}$. The friction coefficient $r$ varies from $0,310^{-5}$ in the open ocean to about $610^{-5} \mathrm{sec}^{-1}$ in shallow waters. The high coefficients determinated experimentally by HANSEN (1951) are for depths below $10 \mathrm{~m}$ and velocities above $100 \mathrm{~cm} / \mathrm{sec}$.

Other assumptions have been made for the friction, especially as related to stresses. PROUDMAN (1953) makes very general use of the friction $\mathrm{R}$ in the form

$\mathrm{R}=\frac{1}{\varrho} \frac{\partial \mathrm{F}}{\partial z}$
where the stress $\mathrm{F}\left(\mathrm{dyne} / \mathrm{cm}^{2}\right)$ is given by
$\mathrm{F}=\varrho \mathrm{k} \mathrm{\textrm {u } ^ { 2 }}$

and the constant $\mathrm{k}$ practically evaluates the friction. For $\mathrm{R}$ follows

$$
\mathrm{R}=\mathrm{k} u \frac{\partial \mathrm{u}}{\partial \mathrm{z}}
$$

and the friction $\mathrm{R}$ depends on the velocity as well as on the velocity gradient. A comparison with the coefficient of linear friction, defined by the relation

$$
\mathrm{R}=\mathrm{ru}
$$




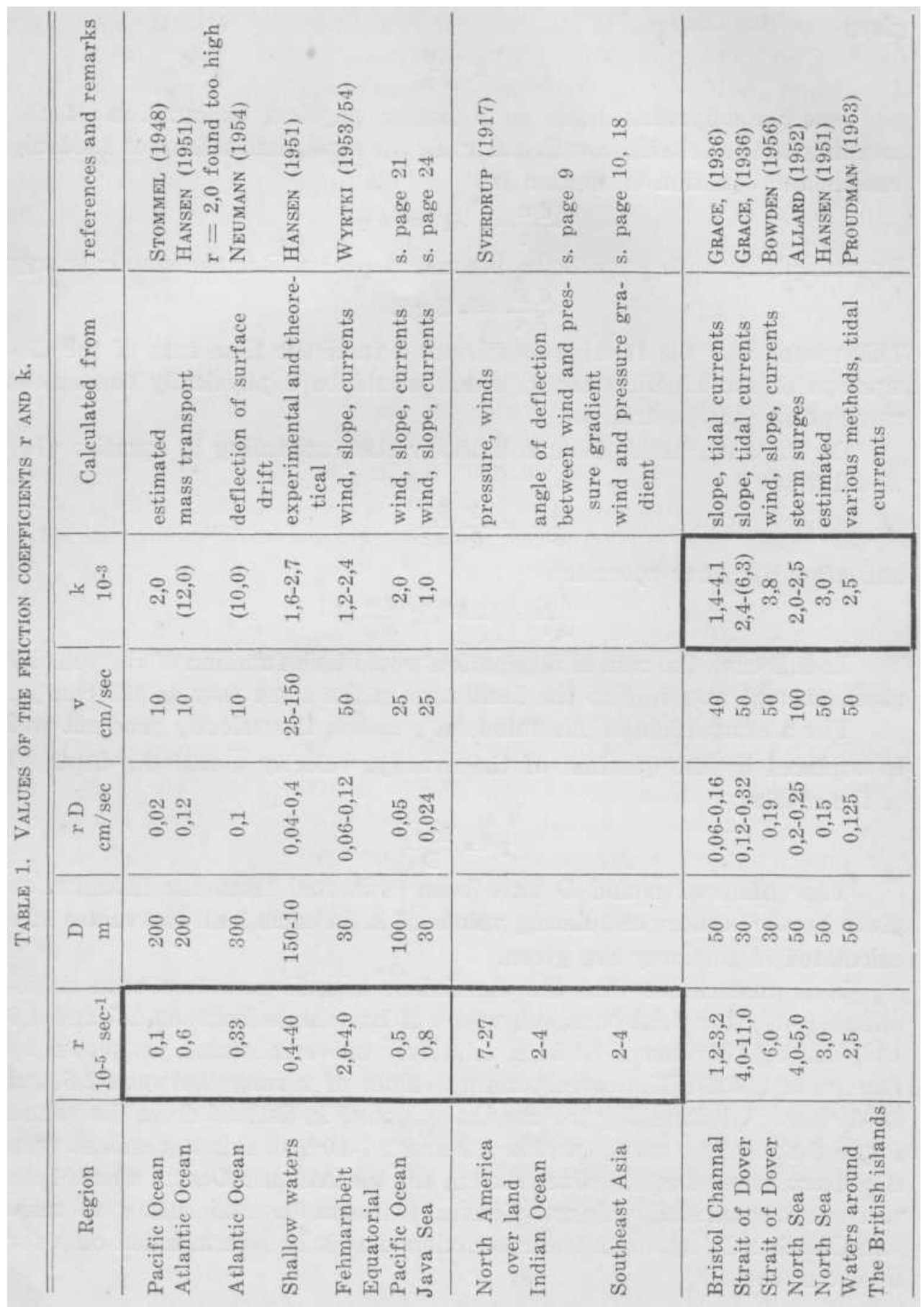


gives

$$
r=k \frac{\partial u}{\partial z} \text {. }
$$

Another approach leads to a better physical explanation of the meaning of the friction coefficient $r$. In the case, that all forces suddenly vanish, the equation of motion is

$$
\frac{\mathrm{du}}{\mathrm{d} \mathrm{t}}=-\mathrm{R}=-\mathrm{r} \mathrm{u}
$$

By multiplying with $\varrho \mathrm{u}$ follows, because $1 / 2 \varrho \mathrm{u}^{2}=\mathrm{E}$ is the kinetic energy

$$
\frac{d E}{d t}=-2 \times E
$$

This means that the friction coefficient $r$ rules the time rate of the dissipation of the kinetic energy, which would be a physically convenient assumption for the friction.

On the other hand, the use of the friction according to equation (14) would give

$\begin{aligned} \frac{\mathrm{du}}{\mathrm{d} t} & =\frac{1}{\varrho} \frac{\partial \mathrm{F}}{\partial \mathrm{z}} \\ \text { and after the same operation } & \frac{\mathrm{dE}}{\mathrm{d} t}=-4 \mathrm{k} \frac{\partial \mathrm{u}}{\partial \mathrm{z}} \mathrm{E}\end{aligned}$

In this case, the rate of dissipation would be a function of the velocity gradient, and would go to the limit zero in the same way as the energy.

For a comparison of the values of $r$ and $k$, the velocity gradient will be replaced by the quotient of the average velocity $u$ and the depth $D$ of the motion,

$$
r=\frac{k \bar{u}}{\mathrm{D}}
$$

The values of $\bar{u}$ and $D$ have been estimated from the information given by the authors calculating values of $\mathrm{k}$. In table 1 all the values of $r$ calculated in this way are given.

It is remarkable that the coefficient $\mathrm{k}$ until now has been determinated only for tidal currents, where it has values between 1,5 and 4,0 $10^{-3}$, and $2,510^{-3}$ seems to be a relatively universal value, as shown by PROUDMAN (1953). The corresponding values of $r$ range between 2,5 and $6,0-10^{-5} \mathrm{sec}^{-1}$. Interesting too are the values of $\mathrm{k}$, derived from the values found for $\mathrm{r}$. These vary between 1,2 and $2,7-10^{-3}$, in fair agreement with the direct determinated values, except for the Atlantic Ocean, where both values are essentially higher. Generally it can be said that $r$ is more variable then $\mathrm{k}$, but with the restriction that $\mathrm{k}$ is determinated only for tidal currents. 
TABLE 2. NUMERICAL VALUES OF THE FACTORS APPEARING IN EQUATIONS (8) AND (11) AS A FUNCTION OF THE GEOGRAPHICAL LATITUDE, FOR THE BOTH FRICTION COEFFICIENTS $r=210^{-5}$ SEC $^{-1}$ AND $r=0,510^{-5}$ sEC $^{-1}$

\begin{tabular}{|c|c|c|c|c|c|c|c|c|}
\hline \multirow{3}{*}{$\varphi$} & \multirow{3}{*}{ y } & \multirow{3}{*}{$\sin \varphi$} & \multirow{3}{*}{$\begin{array}{c}\mathrm{f} \\
2 \omega \sin \varphi\end{array}$} & \multicolumn{2}{|c|}{$r=2 \quad 10^{-5}$} & \multirow{3}{*}{$\frac{1}{f}$} & \multicolumn{2}{|c|}{$\mathrm{r}=0,5 \quad 10^{-5}$} \\
\hline & & & & $\mathbf{r}$ & $f$ & & $f$ & $x$ \\
\hline & & & & $f^{2}+r^{2}$ & $\mathrm{f}^{2}+\mathrm{r}^{2}$ & & $f^{2}+r^{2}$ & $f^{2}+r^{2}$ \\
\hline 0 & 0 & 0.0 & 0.0 & 0.50 & 0.0 & $\infty$ & 0.0 & 2.0 \\
\hline 1 & 1.1 & 0.017 & 0.25 & 0.49 & 0.062 & 4.0 & 0.81 & 1.61 \\
\hline 2 & 2.2 & 0.035 & 0.51 & 0.47 & 0.120 & 1.96 & 1.00 & 0.98 \\
\hline 3 & 3.3 & 0.052 & 0.76 & 0.44 & 0.166 & 1.32 & 0.92 & 0.60 \\
\hline 4 & 4.4 & 0.070 & 1.02 & 0.40 & 0.202 & 0.98 & 0.79 & 0.39 \\
\hline 5 & 5.6 & 0.087 & 1.28 & 0.35 & 0.227 & 0.78 & 0.68 & 0.264 \\
\hline 6 & 6.7 & 0.105 & 1.53 & 0.32 & 0.241 & 0.65 & 0.59 & 0.193 \\
\hline 7 & 7.8 & 0.122 & 1.78 & 0.28 & 0.248 & 0.56 & 0.52 & 0.146 \\
\hline 8 & 8.9 & 0.139 & 2.03 & 0.25 & 0.250 & 0.49 & 0.47 & 0.116 \\
\hline 9 & 10.0 & 0.156 & 2.28 & 0.22 & 0.248 & 0.44 & 0.42 & 0.092 \\
\hline 10 & 11.1 & 0.174 & 2.54 & 0.191 & 0.243 & 0.39 & 0.38 & 0.075 \\
\hline 11 & 12.2 & 0.191 & 2.79 & 0.170 & 0.237 & 0.36 & 0.35 & 0.062 \\
\hline 12 & 13.3 & 0.208 & 3.04 & 0.151 & 0.229 & 0.33 & 0.32 & 0.053 \\
\hline 13 & 14.4 & 0.225 & 3.29 & 0.135 & 0.221 & 0.304 & 0.30 & 0.045 \\
\hline 14 & 15.6 & 0.242 & 3.53 & 0.122 & 0.215 & 0.283 & 0.28 & 0.039 \\
\hline 15 & 16.7 & 0.259 & 3.78 & 0.109 & 0.207 & 0.264 & 0.26 & 0.034 \\
\hline 16 & 17.8 & 0.276 & 4.03 & 0.099 & 0.198 & 0.248 & & 0.030 \\
\hline 17 & 18.9 & 0.292 & 4.26 & 0.090 & 0.192 & 0.234 & 1 & 0.027 \\
\hline 18 & 20.0 & 0.309 & 4.51 & 0.082 & 0.186 & 0.222 & $\frac{1}{f}$ & 0.024 \\
\hline 19 & 21.1 & 0.326 & 4.76 & 0.075 & 0.179 & 0.210 & & 0.022 \\
\hline 20 & 22.2 & 0.342 & 5.00 & 0.069 & 0.172 & 0.200 & & 0.020 \\
\hline 21 & 23.3 & 0.358 & 5.22 & 0.064 & 0.167 & 0.192 & & 0.018 \\
\hline 22 & 24.4 & 0.375 & 5.46 & 0.059 & 0.161 & 0.183 & & 0.017 \\
\hline 23 & 25.6 & 0.391 & 5.70 & 0.055 & 0.156 & 0.175 & & 0.015 \\
\hline 24 & 26.7 & 0.407 & 5.94 & 0.051 & 0.151 & 0.168 & - & 0.014 \\
\hline \multirow[t]{2}{*}{25} & 27.8 & 0.423 & 6.16 & 0.048 & 0.147 & 0.162 & & 0.013 \\
\hline & $10^{7} \mathrm{~cm}$ & & $10^{-5} \mathrm{sec}^{-1}$ & $10^{5} \mathrm{sec}$ & $10^{5} \mathrm{sec}$ & $10^{5} \mathrm{sec}$ & $10^{5} \mathrm{sec}$ & $10^{5} \mathrm{sec}$ \\
\hline
\end{tabular}


When using friction in oceanographic computations, it must be first determined which special assumptions will be made on it. Sometimes the mathematical point of view might prefer a special assumption, because in the other case the mathematical effort would become too voluminous. For the physical point of view, it might be preferable to use the assumption

$$
\mathrm{R}=\mathrm{k} u \frac{\partial \mathrm{u}}{\partial \mathrm{z}}
$$

with the coefficient $\mathrm{k}_{\text {? }}$ in cases where the vertical velocity gradients play an important role, for instance in tidal currents over shollow water, and the assumption

$$
\mathrm{R}=\mathrm{r} \mathrm{u}
$$

with the coefficient $r$, in the open ocean.

In order to get an impression, and for the use in calculations, both factors

$$
\frac{r}{f^{2}+r^{2}} \quad \text { and } \quad \frac{f}{f^{2}+r^{2}}
$$

appearing in equation (8) and (11) have been tabulated together with $\mathrm{f}$ $=2 \omega \sin \varphi$ and $1 / \mathrm{f}$ in table 2 , for the equatorial belt between $25^{\circ} \mathrm{N}$ and $25^{\circ} \mathrm{S}$ and for two friction coefficients $\mathrm{r}=210^{-5} \mathrm{sec}^{-1}$, which is approximately valid in coastal waters, and $\mathrm{r}=0,510^{-5} \mathrm{sec}^{-1}$, which is met in the ocean.

Moreover, it is remarkable that the friction coefficients for the ocean and the atmosphere are approximately the same, which means that the dissipation of energy takes place in about the same way.

Models of atmospheric circulation. To study the properties of simple fields of motion resulting from the application of the linear friction coefficient, some typical cases of circulation across the equator are presented, because there geostropic winds can not be computed, and the effects of the consideration of the friction appear most clearly. The basis is the equation (9) and a friction coefficient $\mathrm{r}=210^{-5} \mathrm{sec}^{-1}$, In $8^{\circ}$ latitude it is $\mathrm{r}$ $=\mathrm{f}=2 \omega \sin 8^{\circ}$.

The first example (Fig. 3) shows the wind distribution computed from isobars parallel to the equator, the high in the north, the low in the south, according to the north monsoon over South East Asia. The isobars are equidistant, which leads to maximal velocities at the equator. This condition is not met normally, as will be shown later. At the equator the direction of the wind is exactly to the south. With increasing latitude it changes rapidly to a more geostrophic direction.

In Fig. 4, the equidistant isobars cross the equator at an angle of $45^{\circ}$, the high lying in the southeast and the low in the northwest. The 


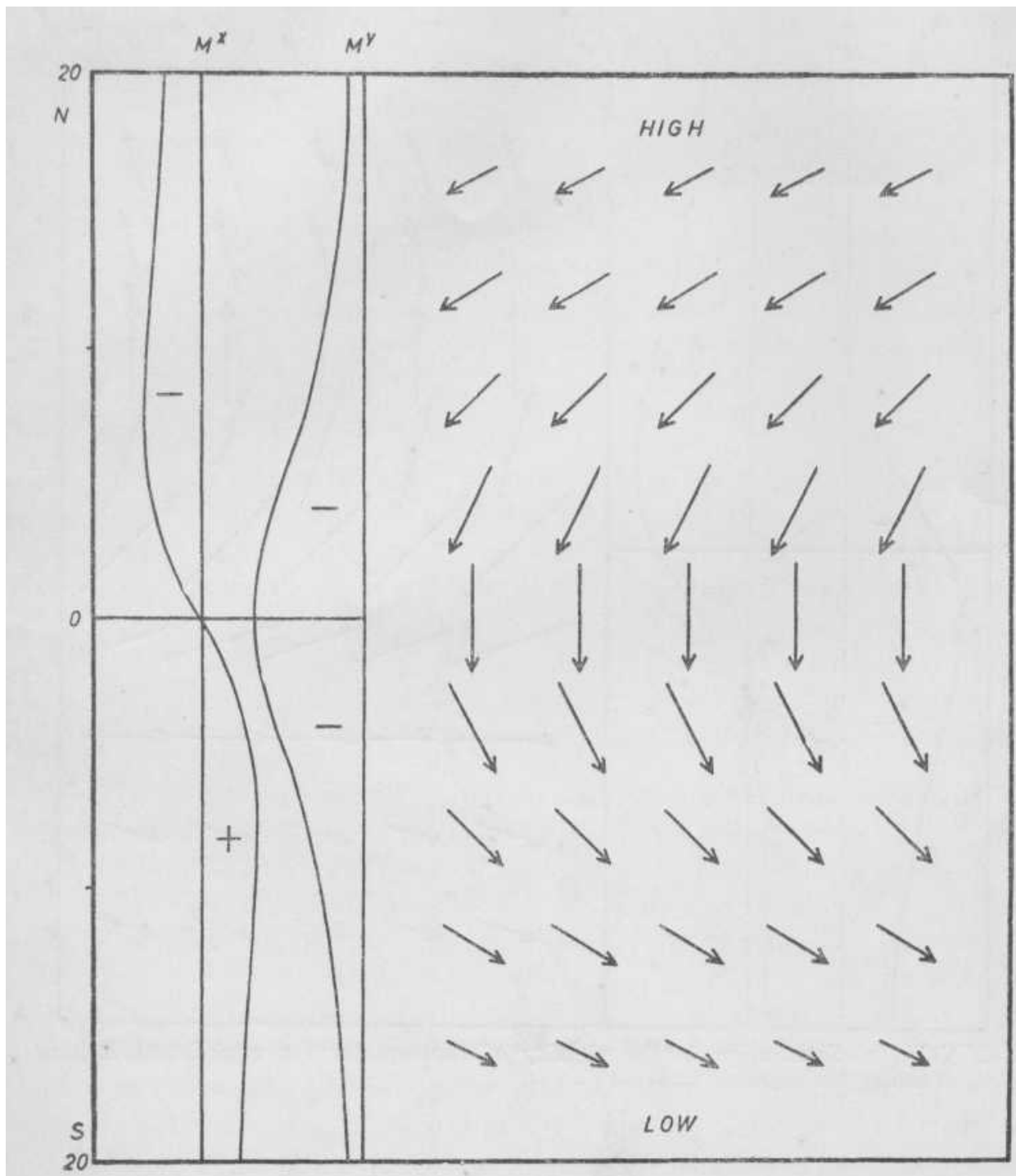

FIG. 3. Velocity distribution in the vicinity of the equator for equidistant isobars parallel to the equator. 


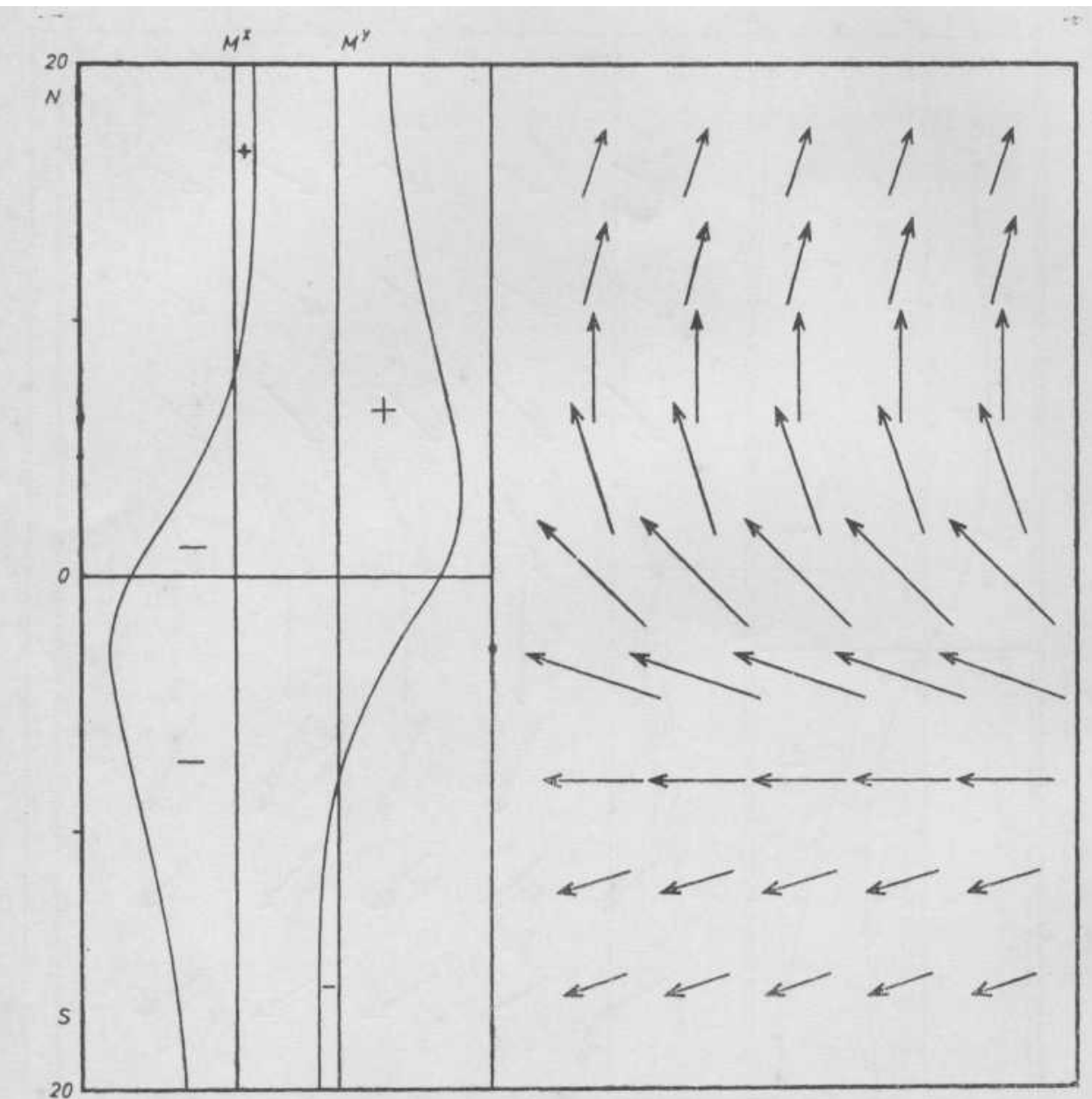

Fig. 4. Velocity distribution in the vicinity of the equator for equidistant isobars crossing the equator under $45^{\circ}$. 


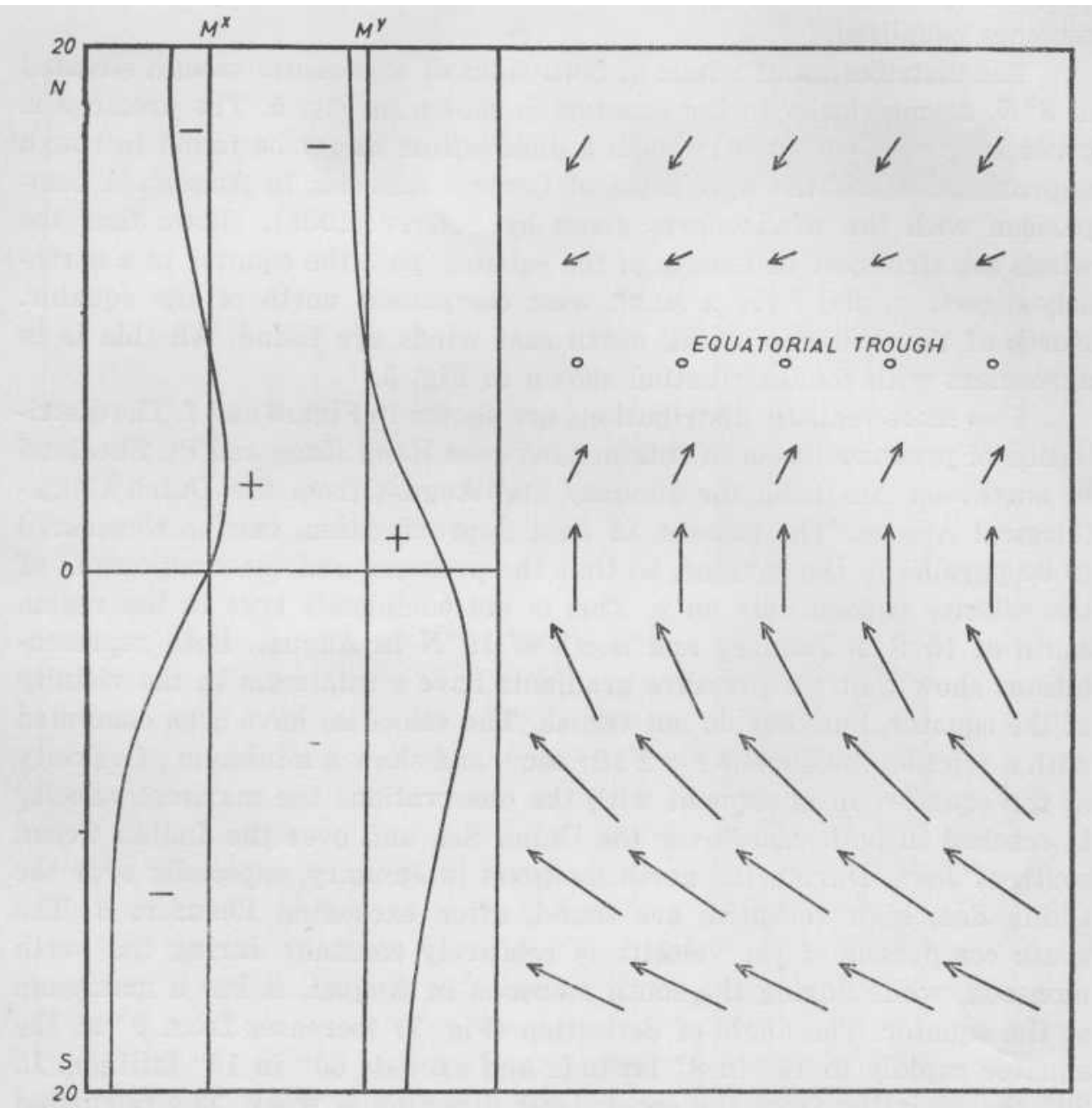

FIG. 5. Velocity distribution in the vicinity of the equator for a pressure trough at $8^{\circ}$ North. 
wind field also shows a typical monsoon character. In contrast to the observations, the maximal velocities are at the equator. In fact, the distribution of pressure will adjust in such a way that the distribution of wind becomes equalized.

The distribution of winds at both sides of a pressure trough situated at $8^{\circ} \mathrm{N}$, asymetrically to the equator, is shown in Fig. 5. The pressure is given by $p=p_{0}-p_{1}(y-a)^{2}$. Such a distribution might be found in rough approximation off the west coast of Central America in August. A comparison with the wind charts given by SCHOTT (1935), shows that the winds are strongest just south of the equator, pass the equator in a northerly direction, and have a small west component north of the equator. North of the doldrums, weak north east winds are found. All this is in agreement with the distribution shown in Fig. 5.

Two more realistic distributions are shown in Figs. 6 and 7. The distribution of pressure has been obtained between Hong Kong and Pt. Shedland in northwest Australia for January and August from the Dutch Climatological Atlases. The isobars, in first approximation, can be considered to be parallel to the equator, so that the pressure and the components of the velocity depend only on $\mathrm{y}$. This is not completely true in the region south of $15^{\circ} \mathrm{S}$ in January and north of $15^{\circ} \mathrm{N}$ in August. Both representations show that the pressure gradients have a minimum in the vicinity of the equator, but they do not vanish. The velocities have been computed with a friction coefficient $\mathrm{r}=210^{-5} \mathrm{sec}^{-1}$, and show a minimum of velocity at the equator. In agreement with the observations the maximal velocity is reached in both cases over the China Sea and over the Indian Ocean south of Java. During the north monsoon in January, especially over the China Sea, high velocities are found, often exceeding Beaufort 6 . The south component of the velocity is relatively constant during the north monsoon, while during the south monsoon in August, it has a maximum at the equator. The angle of deflection (Fig. 7) increases from $0^{\circ}$ at the equator rapidly to $45^{\circ}$ in $8^{\circ}$ latitude and exceeds $60^{\circ}$ in $15^{\circ}$ latitude. In $20^{\circ}$ the deviation from the geostrophic direction is weak. The calculated velocities and their distribution are in fair agreement with the observations shown in both atlases.

Application to the equatorial currents in the Pacific Ocean. The region in which the method can be most effectively proved is the vicinity of the equator, and therefor an attempt to calculate the distribution of velocity in the Central Pacific from the distribution of wind and pressure has been made. The conditions represented in Fig. 8 are approximately 


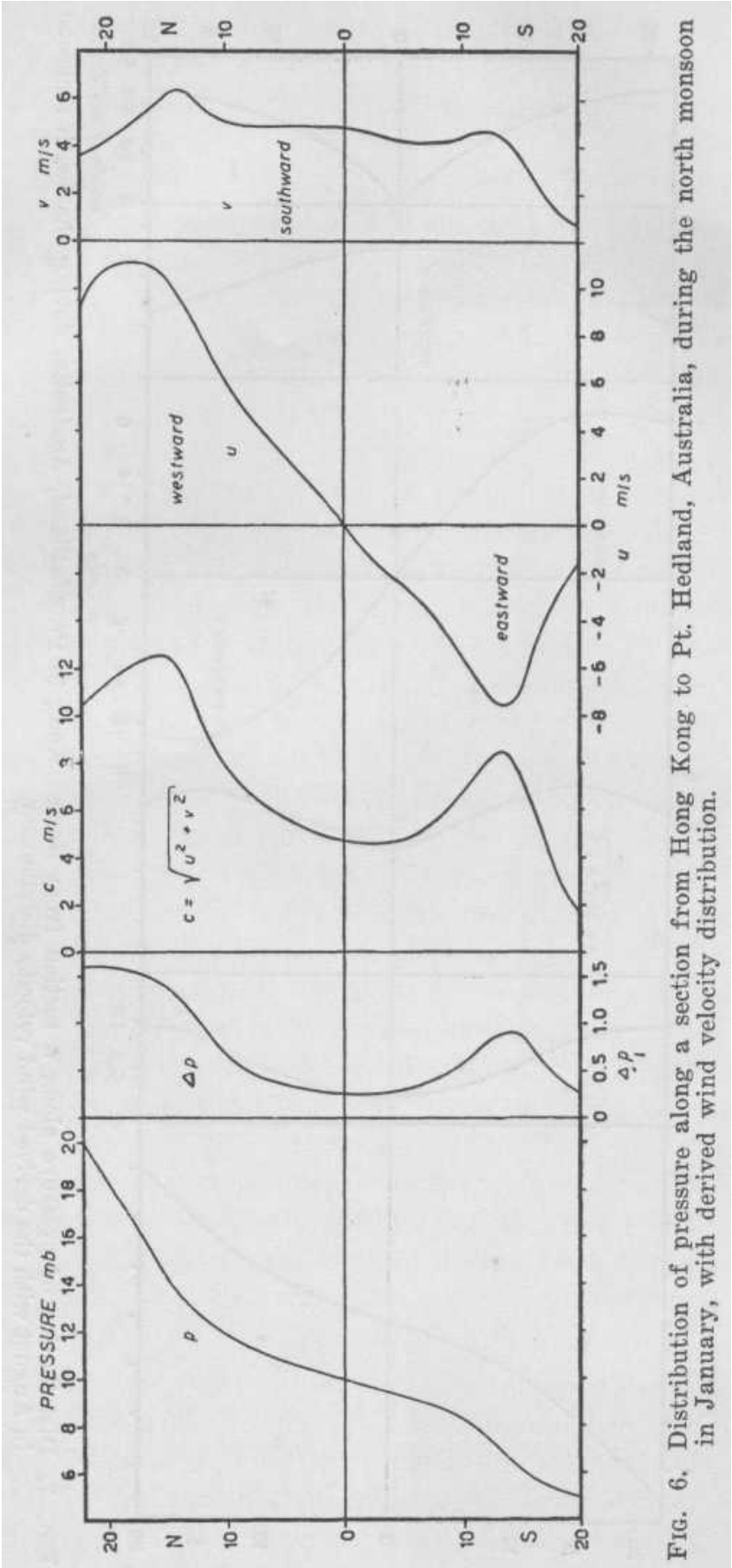




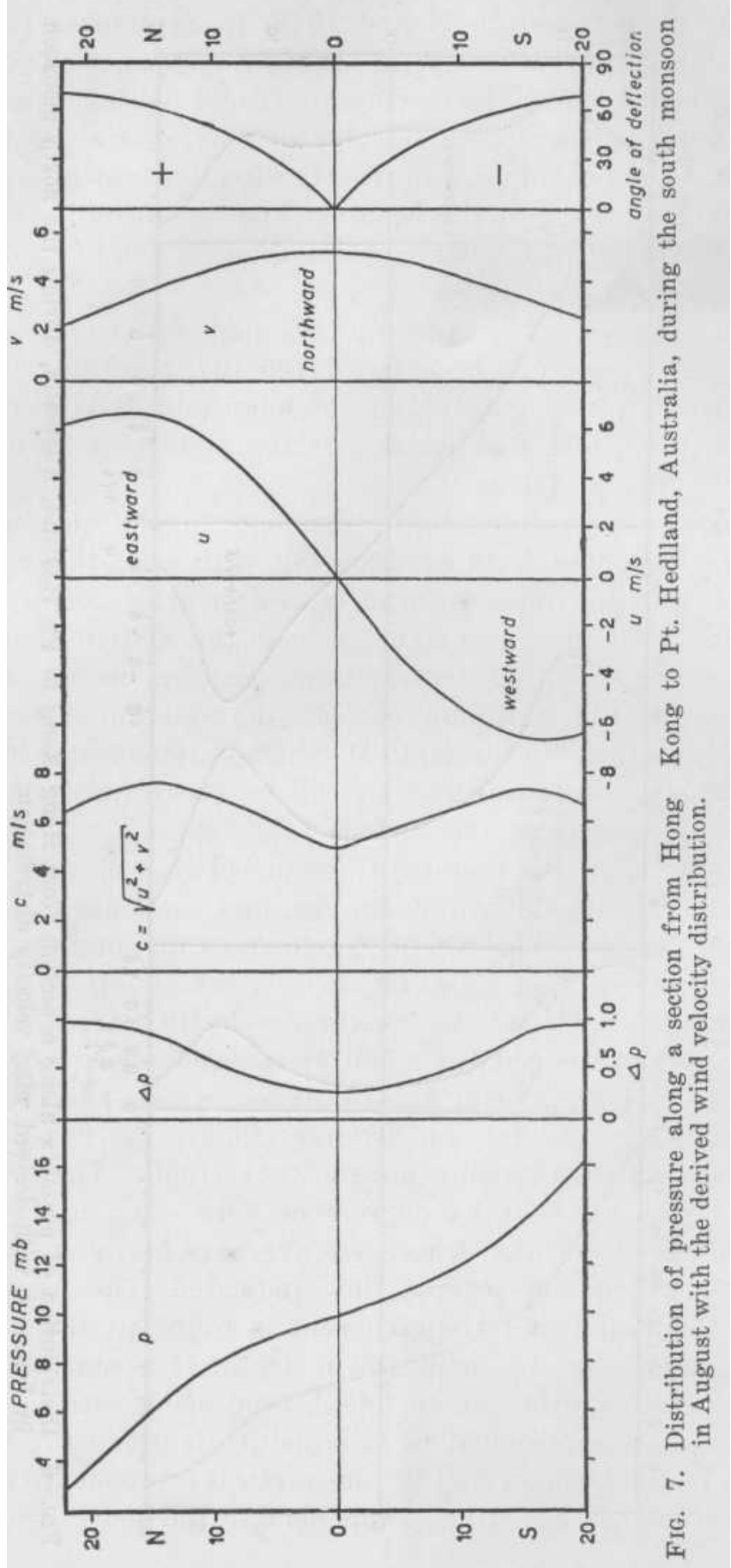


these at $160^{\circ} \mathrm{W}$, between $20^{\circ} \mathrm{N}$ and $10^{\circ} \mathrm{S}$, in September/October, when the Equatorial Counter Current is strongly developed. The components of the wind stress show the northeast Trades with a component in a southerly direction, show the doldrums in $8^{\circ} \mathrm{N}$, and show the southeast Trades with a component in a northerly direction reaching its strongest development just south of the equator. The topography of the sea level has been taken from the Carnegie observations, given by SVERDRUP (1945) relative to the 2000 decibar level.

In Fig. 8 the sea level, as well as the slope $h_{y}$, is presented. The longitudinal slope is computed to be $\mathrm{h}_{\mathrm{x}}=0,4510^{-7}$, according to an increase of the surface of $60 \mathrm{~cm}$ within $120^{\circ}$ of longitude. It is considered to be independent of latitude, because this factor gives only a small contribution to the calculated values.

With these assumptions the components of the mass transport $\mathrm{M}^{\mathrm{x}}$ $\mathrm{M}^{\mathrm{y}}$ have been computed from equation (8), with a friction coefficient $\mathrm{r}=$ $0,510^{-5} \mathrm{sec}^{-1}$. Relating these transports to a layer of $100 \mathrm{~m}$, in which the density is assumed to be constant so that the distribution of pressure might not change essentially, one obtains the components of the velocity $u$ and $v$, shown in Fig. 8. Simultaneously, the equation of continuity gives the vertical movements in the depth $\mathrm{D}$, which is $100 \mathrm{~m}$, showing the regions of descending and ascending motion which are, respectively, the convergences and divergences at the surface.

The results show the Counter Current between $4^{\circ}$ and $10^{\circ} \mathrm{N}$ clearly, with maximal velocities above $50 \mathrm{~cm} / \mathrm{sec}$, and show also a southern component at the surface. The North Equatorial Current is relatively weak and reaches velocities of only $14 \mathrm{~cm} / \mathrm{sec}$, while the South Equatorial Current exceeds $25 \mathrm{~cm} / \mathrm{sec}$. Its maximal velocities are on both sides of the equator, and at the equator a belt of reduced velocities is found. This belt might be the Equatorial Undercurrent, which has been discovered by Cromwell, MONTGOMERY and STROUP (1954), and has been explained theoretically by FOFONOFF and MONTGOMERY (1955). The belt of reduced velocities extends to about 1,5 degrees on both sides of the equator. Because the velocities calculated here are averages between the surface and $100 \mathrm{~m}$, there will be no reverse flow indicated. The maximum of the velocity of the Equatorial Undercurrent is found at the upper limit of the discontinuity layer in about $100 \mathrm{~m}$ depth. It is surprising that such a detail of the circulation can be found, even using such simple methods.

A remarkable supplement to this picture is given by the meridional components of the velocity and by the vertical components in $100 \mathrm{~m}$. The Counter Current has a distinct component to the south, while the North 


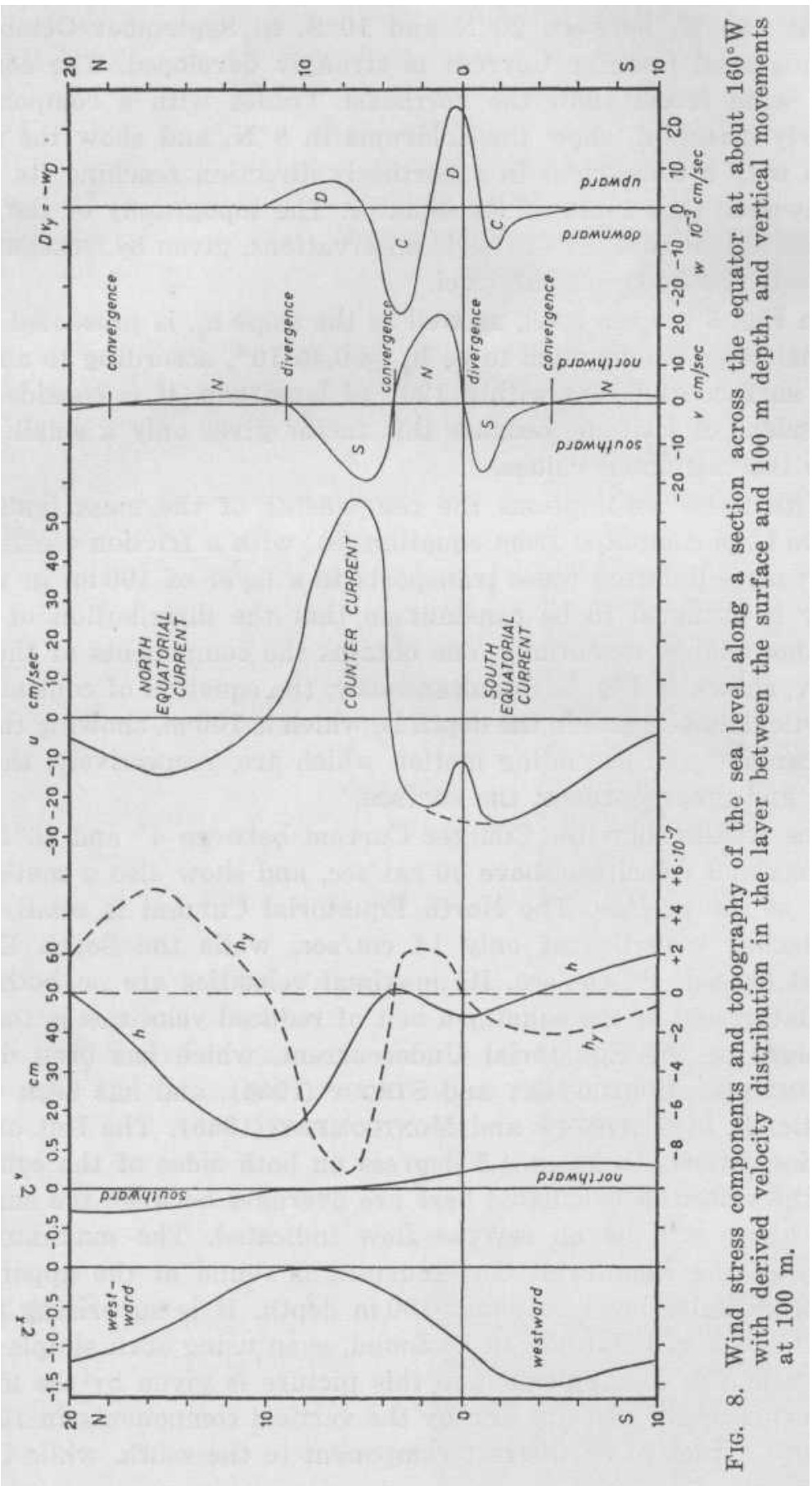


Equatorial Current has a weak northerly component, producing at their boundary a divergence. This is characterised also in the vertical motion in $100 \mathrm{~m}$, and reaches from about $5^{\circ}$ to $11^{\circ} \mathrm{N}$ with ascending motion. At the boundary between the Counter Current and the South Equatorial Current a convergence is formed with descending movements in the depth. Interesting is the solution at the equator itself. The movements are northward north of the equator and southward south of the equator, producing a divergence at the equator and ascending motions in the depth. In about $2^{\circ} \mathrm{S}$, again a region of descending motion is found in connection with a convergence at the surface at about $5^{\circ} \mathrm{S}$. This picture of the movements is in fair agreement with that derived by SVERDRUP (1946, p. 710) from the distribution of different properties along a section crossing the equator. These calculations, however, do not allow arriving at conclusions on the reason of the pressure distribution. Observed wind stresses and the pressure distribution are required in this method, from which the distribution of movements can be computed. On the other hand, SVERDRUP (1947) has shown that it is possible to compute the distribution of pressure or, identically, the topography of the sea level, from the distribution of wind stress. With this he has demonstrated that the whole current system near the equator is an effect of the wind distribution. The computation of motion by means of the observed pressure and wind distribution used in this paper, however, gives more detail of the motion, and especially of the vertical movements, which are of importance for the explanation of various effects. Therefore, this treatment is especially suitable for the interpretation of oceanographic observations in only parts of the oceans.

Application of the method for channels. Channels or other passages often allow very simple applications of the equation (7). It is reasonable to assume that the mass transport across the channel vanishes, at least its integral from one boundary to the other. Putting the coordinate system in such a way that the $\mathrm{x}$-axis points in the direction of the channel, and integrating over the width $b$ of the channel, one obtains

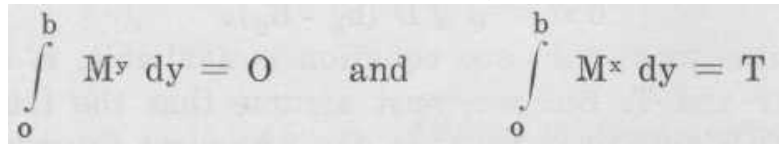

where $\mathrm{T}$ is the transport in $\mathrm{g} / \mathrm{sec}$. With the assumption that the wind stress $\tau$ is independent of $y$, the first both equations of (7) are

$$
\begin{aligned}
& \mathrm{r} \mathrm{T}=\mathrm{b} \tau^{\mathrm{x}}-\varrho \mathrm{g} \mathrm{D} \mathrm{b} \mathrm{h}_{\mathrm{x}} \\
& \mathrm{f} \mathrm{T}=\mathrm{b} \tau^{\mathrm{y}}-\varrho \mathrm{g} \mathrm{D}\left(\mathrm{h}_{\mathrm{b}}-\mathrm{h}_{\mathrm{o}}\right)
\end{aligned}
$$


where $h_{b}-h_{o}$ is the difference of the sea level between both shores. Considering at first a wind blowing parallel to the channal, $\tau^{\mathrm{y}}=0$, as it is during the monsoons over the Java and China Seas, and of a vanishing slope in the direction of the channal, $\mathrm{h}_{\mathrm{x}}-0$, which is fixed by observations, the system (15) is reduced to

$$
\begin{aligned}
& r \mathrm{~T}=\mathrm{b} r^{\mathrm{x}} \\
& \mathrm{fT}=-\varrho \mathrm{g} \mathrm{D}\left(\mathrm{h}_{\mathrm{b}}-\mathrm{h}_{\mathrm{o}}\right)
\end{aligned}
$$

These equations allow the elimination of two factors, for instance of the friction $\mathrm{r}$ and of the transport $\mathrm{T}$, if the windstress $\tau$ and the sea level difference $\left(h_{b}-h_{o}\right)$ are known, as well as the dimensions of the channel. For the Java Sea during the south east monsoon these are approximately

$$
\begin{aligned}
& \tau^{\mathrm{x}}=-0,8 \mathrm{dyne} / \mathrm{cm}^{2}, \mathrm{~b}=310^{7} \mathrm{~cm}, \mathrm{D}=3010^{2} \mathrm{~cm}, \\
& \mathrm{f}=2 \omega \sin 5^{\circ}=1,210^{-5} \mathrm{sec}^{-1},\left(\mathrm{~h}_{\mathrm{b}}-\mathrm{h}_{\mathrm{o}}\right)=12 \mathrm{~cm}
\end{aligned}
$$

with the solution

$$
\begin{aligned}
& \mathrm{T}=-310^{12} \mathrm{~g} / \mathrm{sec} \sim 3 \text { million } \mathrm{m}^{3} / \mathrm{sec} \\
& \mathrm{r}=0,810^{-5} \mathrm{sec}^{-1}
\end{aligned}
$$

The average velocity over the whole section is computed from $\mathrm{v} b \mathrm{D}=$ $\mathrm{T}$ and gives $33 \mathrm{~cm} / \mathrm{sec}$, which is in agreement with the observations. The friction $r$ is larger than in the open ocean, but lower than in the narrower channel of the Fehmarn-Belt, see table 1. Carrying out the computation in this way, the cross slope seems to be the ruling factor. Actually, the transport is produced by the wind stress with the friction as limiting factor. But because of the coriolis acceleration, there is a component vertical to the wind, which must be balanced by a cross slope, which is maintained by that wind.

In the southern part of the China Sea, just below the equator, the conditions are rather different. Here is $\mathrm{f}=\mathrm{O}$, and the wind is in the direction of the channel. It follows from equations (15) that

$$
\mathrm{r} \mathrm{T}=\mathrm{b} \tau^{\mathrm{x}}
$$

while the left side of the second equation vanishes. A cross slope can be produced only by a west - east component of the wind, and does not affect the transport

$$
\mathrm{b} \tau^{y}=\varrho \mathrm{g} \mathrm{D}\left(\mathrm{h}_{\mathrm{b}}-\mathrm{h}_{\mathrm{o}}\right) \text {. }
$$

Because, in this case, only one equation is available, it is impossible to determinate $r$ and $\mathrm{T}$. But we must assume that the transport through the southern China Sea is equal to the transport through the Java Sea at the same time. Therefore it is

and with it

$$
\mathrm{T}=310^{12} \mathrm{~g} / \mathrm{sec} \quad \mathrm{b}=410^{7} \mathrm{~cm} \quad \tau^{\mathrm{x}}=0,6 . \text { dyne } / \mathrm{cm}^{2}
$$

$$
\mathrm{r}=0,810^{-5} \mathrm{sec}^{-1}
$$


which is the same friction as in the Java Sea, If such a transport should be maintained by a longitudinal slope, it would have to be

$$
\mathrm{rT}=-\varrho \mathrm{g} \mathrm{D} \mathrm{b} \mathrm{h}_{\mathrm{x}}
$$

and with the values used above

$$
\mathrm{h}_{\mathrm{x}}=310^{-7}
$$

But a stationary slope of $310^{-7}$, which is $15 \mathrm{~cm}$ within $5^{\circ}$ of latitude, does not appear in these waters in the direction of the current. This might appear only in tidal currents, where the slope is not stationary. In the China Sea the conditions during the south west monsoon are rather different. The wind stress $\tau^{\mathrm{x}}=0,9$ would produce a transport of $\mathrm{T}=8$ $10^{12} \mathrm{~g} / \mathrm{sec}$, using a width of the channel $\mathrm{b}-700 \mathrm{~km}$, and a friction $\mathrm{r}-0,8$ $10^{-5} \mathrm{sec}^{-1}$. But such a transport does not appear, because only $310^{12} \mathrm{~g} / \mathrm{sec}$ of water will be delivered from the Java Sea. Therefore, a part of the wind stress must be compensated by a longitudinal slope of the sea level against the current. Using the first equation of (15) with $\mathrm{D}=80 \mathrm{~m}$, and a slope of $16 \mathrm{~cm}$ on 20 degrees of latitude, according to observations, it is

$$
\mathrm{r} \mathrm{T}=\mathrm{b}\left(\mathrm{\tau}^{\mathrm{x}}-\varrho \mathrm{g} \mathrm{D} \mathrm{h}_{\mathrm{x}}\right)
$$

and with $\mathrm{T}=310^{12} \mathrm{~g} / \mathrm{sec}$ follows a friction $\mathrm{r}=0,610^{-5} \mathrm{sec}^{-1}$.

This friction is smaller than in the Java Sea, because the currents do not touch the bottom in the largest parts of the region. From the second equation of (15), the cross slope can be calculated to be $11 \mathrm{~cm}$ over the full width of the channel, if there is no wind component across the channel. This is in agreement with the observations too. The velocity can be computed from the transport, the width of the channel and the depth of the current, to average $4,2 \mathrm{~cm} / \mathrm{sec}$ between the surface and $80 \mathrm{~m}$. Because the velocity vanishes at $80 \mathrm{~m}$, it will be about $10 \mathrm{~cm} / \mathrm{sec}$ at the surface, which agrees closely with the observations.

\section{REFERENCES}

Allard, P., 1952. C. O. E. C. Bull. Inform. 4, 307.

BowDEn, K. F., 1956. The flow of water through the Strait of Dover. Phil. Trans. Roy. Soc. Lond. No. 953, Vol. 248.

Cromwell, T., Montgomery, R. B. and Stroup, E. D., 1954. Equatorial Undercurrent in Pacific Ocean revealed by new methods, Science, 119.

Defant, A., 1941. Die absolute Topographie des physikalischen Meeres niveaus und der Druckflachen sowie die Wasserbewegungen im Raum des Atlantischen Oceans. Meteor-Expedition, Vol. 6, Teil 2,5.

Fofonoff, N. P. and Montgomery, R. B., 1955. The Equatorial Undercurrent in the light of the Vorticity Equation. Tellus, 7,4.

GRACE, S. F., 1936. Friction in the tidal currents of the English Channel. Geophys. Suppl. M. N. R. Astr. Soc. Vol. 4, p. 133. 
Hansen, W., 1951. Beobachtungen des Windstaus und Triftstroms im Modellkanal. Dtsch. Hydr. Z. Bd. 4, Heft 3.

Hansen, W., 1951. Winderzeugte Stromungen im Ozean Dtsch. Hydr. Z. Bd. 4, Heft 4.

HANSEN, W., 1952. Dtsch. Hydr. Z. Erganzungsheft 1.

HIDAKA, K., 1950. Lateral mixing and wind driven currents in an enclosed ocean. Journ. Mar. Res. Vol. 9, p. 55.

HIDAKA, K., 1955. A theoretical Study on the general circulation of the Pacific Ocean. Pacific Science, Vol. 9, p. 183.

HIDAKA, K., 1955. Divergence of surface drift currents in terms of wind stresses. Jap. Journ. of Geophy. Vol. 1, No. 2.

MunK, W. H., 1950. On the wind driven ocean circulation. Journ. Meteorology. Vol. 7, No. 2.

NeumanN, G., 1954. Notes on the wind driven ocean circulation. New York Univ., Dept. of Meteor, and Ocean.

Proudman, J., 1953. Dynamical Oceanography, London, 1953.

Rossby, C. C, 1936. Dynamics of steady ocean currents in the light of experimental fluid mechanics. Pap. Phys. Ocean. Meteor. 5, 1.

Sснотт, G., Geographie des Indischen und Stillen Oceans, Hamburg, 1935.

StOMmEL, H., 1948. The westward intensification of wind driven ocean currents. Trans. Amer. Geophy. Union, 29, 2.

Sverdrup, H. U. and J. HoltSMARK, 1917. Veroff. Goephy. Inst, Leipzig, 2, 2, 97. SVERDROP, H. U. a.o. 1945. Carnegie Expedition, Oceanography, I B.

SVERDRUP, H. U. a.o. 1946. The Oceans, New York 1946.

SVERDRUP, H. U. a.o. 1947. Wind driven currents in a baroclinic ocean. Proc. Nat. Acad. Sci. 33, p. 318.

WuST, G., 1950. Blockdiagramme der atlantischen Zirkulation. Kieler Meeresforsch. 7,1. WYRTKI, K., 1953, 1954. Die Dynamik der Wasserbewegungen im Fehmarnbelt, Kieler Meeresforsch. 9,2 u. 10,2.

Sea areas round Australia, Koninklijk Nederlands Meteorol. Inst., No. 124. Oceanographic and meteorological observations in the China Sea. Koninklijk Neder lands Meteorolog. Inst. No. 115, 1936. 